\title{
Sediment Analysis
}

National Cancer Institute

\section{Source}

National Cancer Institute. Sediment Analysis. NCI Thesaurus. Code C105744.

An observation, assessment or examination of the sediment in a sample. 